\title{
Hubungan Kadar Gula Darah Sewaktu Dengan Kualitas Tidur Pada Lansia Beresiko Diabetes Melitus Di Posyandu Desa Kincang Wetan Kota Madiun
}

\author{
${ }^{1}$ Tantia Dewi Harianto, ${ }^{2}$ Nungki Marlian Yuliadarwati, ${ }^{3}$ Atika Yulianti \\ Program Studi S1 Fisioterapi, Fakultas Ilmu Kesehatan, Universitas Muhammadiyah Malang \\ Jl. Bandung No. 1 Malang, East Java, Indonesia 65113 \\ Email: tntiadwi29@gmail.com
}

Tanggal Submisi: 5 September 2020; Tanggal Penerimaan: 21 Juni 2021

\begin{abstract}
ABSTRAK
Latar belakang: Di Indonesia angka kejadian diabetes melitus mencapai peringkat 5 dunia berdasarkan Federasi Diabetes Internasional. Diabetes melitus adalah kondisi kadar gula darah tinggi (hiperglikemi). Kadar gula darah tinggi menimbulkan gejala yang dapat mempengaruhi kualitas tidur pada malam hari. Lansia sering mengalami kualitas tidur buruk karena proses penuaan. Kualitas tidur buruk berdampak pada kemampuan aktivitas sehari-hari. Tujuan: untuk mengetahui hubungan kadar gula sewaktu dengan kualitas tidur pada lansia beresiko diabetes melitus di Posyandu Desa Kincang Wetan Kota Madiun. Metode penelitian: penelitian bersifat desktriptif analitik menggunakan pendekatan observasional dengan disain penelitian cross sectional jumlah sampel 61 orang diambil dengan teknik Purposive Sampling dengan mengukur kadar gula darah sewaktu menggunakan glucotest dan memberikan kuisioner kualitas tidur Pittsburgh Sleep Quality Index (PSQI) dalam pengambilan data. Hasil: hasil penelitian menggunakan Spearman rho didapatkan nilai signifikansi 0,001 atau $\mathrm{p}<0,05$ sehingga $\mathrm{H}_{1}$ diterima dan $\mathrm{H}_{0}$ ditolak. Kesimpulan: terdapat hubungan antara kadar gula darah sewaktu dengan kualitas tidur pada lansia beresiko diabetes melitus di Posyandu Desa Kincang Wetan Kota Madiun.
\end{abstract}

Kata kunci: Kadar gula sewaktu, Kualitas tidur, Lansia, Diabetes Melitus

\begin{abstract}
Background: In Indonesia the incidence of diabetes mellitus reaches the world number 5 based on the International Diabetes Federation. Diabetes mellitus is a condition of high blood sugar levels (hyperglycemia). High blood sugar levels cause symptoms that can affect the quality of sleep at night. The elderlies often experience poor sleep quality due to the aging process. Poor sleep quality affects the ability of daily activities. Objective: to determine the relationship of sugar levels when with the quality of sleep in the elderly at risk of diabetes mellitus in Posyandu, Kincang Wetan Village, Madiun City. Research methods: Descriptive analytic study using an observational approach with a cross sectional study design with a sample of 61 people taken by purposive sampling technique by measuring blood sugar levels while using glucotest and giving a Pittsburgh Sleep Quality Index (PSQI) sleep quality questionnaire in data collection. Results: the results of the study using Spearman rho obtained a significance value of 0,001 or $\mathrm{p}<0,05$ so that $\mathrm{H}_{1}$ was accepted and $\mathrm{H}_{0}$ was rejected. Conclusion: there is a relationship between blood sugar levels and the quality of sleep in the elderly at risk of diabetes mellitus in Integrated Healthcare Center of Kincang Wetan Village, Madiun City.
\end{abstract}

Keywords: Current sugar levels, Sleep quality, Elderly, Diabetes Mellitus

ISSN 2722-9610 


\section{PENDAHULUAN}

Penuaan merupakan tahap akhir dari kehidupan seseorang. Orang yang mengalami penuaan biasa disebut dengan lanjut usia (lansia), ditandai dengan perubahan fungsi tubuh yang cenderung menurun secara bertahap dalam waktu ke waktu (Fatimah, 2010). Penuaan membuat lansia menjadi lebih rentan terkena penyakit karenan sistem imun yang menurun (Adriani \& Wirtajmadi, 2012). Efek dari penurunan sistem imun menyebabkan tubuh mudah terserang banyak penyakit. Hasil dari Riskesdas (2013), penyakit terbanyak pada lansia adalah Penyakit Tidak Menular (PTM) antara lainhipertensi, arthritis, stroke, Penyakit Paru Obstriksi Kronik (PPOK), kanker, jantung koroner, gagal jantung, gagal ginjal, batu ginjal dan diabetes melitus.

Diabetes Melitus (DM) adalah sekelompok penyakit metabolik yang ditandai dengan hiperglikemi atau kadar gula darah tinggi yang disebabkan dari gangguan sekresi insulin, kerja insulin atau keduanya (ADA, 2014). Kadar gula darah merupakan sejumlah glukosa yang terdapat didalam darah (Dorland, 2010). Glukosa merupakan pecahan dari karbohidrat yang akan diserap tubuh dalam aliran darah, glukosa berperan sebagai bahan bakar utama dalam tubuh yang fugsinya menghasilkan energi (Amir, 2015). Kualitas tidur adalah kemampuan setiap orang untuk mempertahankan keadaan tidur dan untuk mendapatkan tahap Rapid Eye Movement (REM) dan Non Rapid Eye Movement (NREM) (Kozier dkk, 2004 dalam Agustin, 2012). Kualitas tidur yang baik diperlukan untuk membantu pembentukan sel - sel tubuh yang baru, memperbaiki sel - sel tubuh yang rusak, memberi waktu organ tubuh untuk beristirahat dan menjaga keseimbangan metabolisme dan biokimiawi tubuh (Guyton \& Hall, 2010). Kadar gula darah yang tinggi didalam tubuh dapat beresiko diabetes melitus dan dicurigai akan mempengaruhi kualitas tidur lansia.

\section{METODE PENELITIAN}

Jenis desain penelitian yang digunakan oleh peneliti yaitu dengan pendekatan Cross Sectional. Penelitian dilaksanakan selama satu bulan di posyandu dusun 4 Desa Kincang Kota Madiun dengan jumlah responden 64 orang, namun yang memenuhi kriteria inklusi sebanyak 61 orang. Penelitian ini menggunakan alat ukur glucotest untuk mengukur kadar gukla darah sewaktu sedangkan kualitas tidur menggunakan Pittsburgh Sleep Quality Index (PSQI). Karakteristik responden dalam penelitian ini adalah usia, jenis kelamin, indeks massa tubuh, kadar gula darah sewaktu dan kualitas tidur. Penelitian ini menggunakan uji Spearman Rho.

\section{HASIL}

Tabel 1 Karakteristik Responden Berdasarkan Usia (Sumber: Data Primer, 2020)

\begin{tabular}{ccc}
\hline Usia & Jumlah & Presentase \\
\hline Elderly & 54 & $88,5 \%$ \\
Old & 7 & $11,5 \%$ \\
\hline Jumlah & 61 & $100 \%$ \\
\hline
\end{tabular}

Pada tabel 1 menggambarkan karakteristik responden berdasarkan usia dengan kelompok usia elderly sebanyak 54 orang $(88,5 \%)$ dan old 7 orang $(11,5 \%)$.

Tabel 2 Karakteristik Responden Berdasarkan Jenis Kelamin (Sumber: Data Primer, 2020)

\begin{tabular}{ccc}
\hline Jenis Kelmain & Jumlah & Presentase \\
\hline Laki - laki & 6 & $9,8 \%$ \\
Perempuan & 55 & $90,2 \%$ \\
\hline Jumlah & 61 & $100 \%$ \\
\hline
\end{tabular}

Pada tabel 2 dapat dilihat bahwa distribusi responden jenis kelamin laki - laki 6 orang $(9,8 \%)$ dan perempuan sebanyak 55 orang $(90,2 \%)$. 
Tabel 3 Karakteristik Responden Berdasrkan

Indeks Massa Tubuh (IMT) (Sumber: Data

Primer, 2020)

\begin{tabular}{ccc}
\hline IMT & Jumlah & Presentase \\
\hline $\begin{array}{c}\text { Berat Badan } \\
\text { Kurang }\end{array}$ & 6 & $9,8 \%$ \\
$\begin{array}{c}\text { Berat Badan } \\
\text { Ideal }\end{array}$ & 27 & $44,3 \%$ \\
$\begin{array}{c}\text { Berat Badan } \\
\text { Lebih }\end{array}$ & 23 & $37,7 \%$ \\
Gemuk & 5 & $8,2 \%$ \\
\hline Jumlah & 61 & $100 \%$ \\
\hline
\end{tabular}

Pada tabel 3 dijelaskan bahwa distribusi responden berdasarkan indeks massa tubuh yaitu berat badan kurang sebanyak 6 orang $(9,8 \%)$, berat badan ideal sebanuak 27 orang (44,3\%), berat badan lebih sebanyak 23 orang $(37,7 \%)$ dan gemuk sebanyak 5 orang $(8,2 \%)$.

\begin{tabular}{ccc}
$\begin{array}{c}\text { Tabel } 4 \text { Karakteristik Responden Berdasarkan } \\
\text { Kadar Gula Darah Sewaktu (Sumber: Data } \\
\text { Primer, 2020) }\end{array}$ \\
\hline $\begin{array}{c}\text { Kadar Gula } \\
\text { Darah }\end{array}$ & Jumlah & Presentase \\
Sewaktu & & \\
\hline Normal & 23 & $37,7 \%$ \\
Prediabetes & 33 & $54,1 \%$ \\
Diabetes & 5 & $8,2 \%$ \\
\hline Jumlah & 61 & $100 \%$ \\
\hline
\end{tabular}

'Pada tabel 4 dijelaskan hasil distribusi data responden yang memiliki kadar gula darah sewaktu normal sebanyak 23 orang $(37,7 \%)$, prediabetes sebanyak 33 orang $(54,1 \%)$ dan diabetes sebanyak 5 orang $(8,2 \%)$.

Tabel 5 Karakteristik Responden Berdasarkan Kualitas Tidur (Sumber: Data Primer, 2020)

\begin{tabular}{|c|c|c|}
\hline $\begin{array}{c}\text { Kualitas } \\
\text { Tidur }\end{array}$ & Jumlah & Presentase \\
\hline Baik & 6 & $9,8 \%$ \\
\hline Buruk & 55 & $90,2 \%$ \\
\hline Jumlah & 61 & $100 \%$ \\
\hline Pada & tabel 5 & menggambarka \\
\hline
\end{tabular}

karakteristik responden yang memiliki kualitas tidur baik sebanyak 6 orang $(9,8 \%)$ dan kualitas tidur buruk sebanyak 55 orang $(90,2 \%)$.

Tabel 6 Uji Normalitas (Sumber: Data Primer, 2020)

\begin{tabular}{lcc}
\hline & sig & $\boldsymbol{\alpha}$ \\
\hline Kadar Gula & 0,000 & 0,05 \\
$\quad$ Darah & & \\
Sewaktu & & \\
Kualitas & 0,000 & 0,05 \\
$\quad$ Tidur & & \\
\hline Keterangan; Uji Kolmogor-smirnov; Sig: signifikansi
\end{tabular}

Berdasarkan tabel 6 hasil uji normalitas kolmogorov-smirnov di dapatkan nilai signifikansi 0,000 artinya $p<0,05$ atau 0,000 kurang dari 0,05 sehingga sebaran data tidak normal.

Tabel 7 Uji Korelasi (Sumber: Data Primer, 2020)

\begin{tabular}{ccc}
\hline & $\begin{array}{c}\text { Correlation } \\
\text { Coefficient }\end{array}$ & $\begin{array}{c}\text { Sig. (2- } \\
\text { tailed) }\end{array}$ \\
\hline Hubungan & 0,419 & 0,001 \\
kadar gula & & \\
darah & & \\
sewaktu & \\
dengan & \\
kualitas tidur & \\
\hline Keterangan; Uji Spearman rho; Sig: signifikansi
\end{tabular}

Dari hasil uji korelasi menggunakan uji Spearman Rho didapatkan hasil nilai $\mathrm{p}=0.001$ yang artinya $\mathrm{p}<0.05$, sehingga $\mathrm{H}_{1}$ diterima $\mathrm{H}_{0}$ ditolak, yang artinya terdapat hubungan antara kadar gula darah sewaktu dengan kualitas tidur pada lansia di Posyandu Desa Kincang Wetan Kota Madiun dengan nilai correlation coefficient 0,419 .

\section{PEMBAHASAN}

\section{Karakteristik Responden Berdasarkan Usia}

Dari hasil penelitian didapatkan kesimpulan sebagian besar lansia dengan 
kelomnpok usia 60 - 74 tahun (Elderly) yang memiliki resiko terkena diabetes melitus. Dalam penelitian Tentro dkk (2016) mengatakan diabetes melitus cenderung berkembang lebih cepat pada usia 50 - 65 tahun, semakin bertambah usia resiko mengalami diabetes melitus lebih tinggi. Usia lanjut dapat mempengaruhi penurunan pada sistem tubuh terutama pada sistem endokrin yang menyebabkan terjadinya resistensi insulin yang berakibat tidak stabilnya kadar glukosa dalam tubuh sehingga dapat menyebabkan terjadinya penyakit DM (Isnaini \& Ratnasari, 2018 dalam Uyun 2019).

Seiring dengan bertambahnya usia dan proses penuaan, akan berdampak pada terjadinya perubahan pola tidur seseorang (Wolkove dkk, 2007). Menurut Roizen \& Mehmet, (2009) dalam Soamole, (2017), usia diatas 60 tahun dapat menyebabkan terjadinya penurunan kualitas tidur. Hal tersebut karena secara fisiologis dengan bertambahnya usia maka seseorang akan mengalami penurunan jumlah hormon melatonin didalam tubuh yang dapat mempengaruhi tidur (Roizen \& Mehmet, 2009). Menurut Sari \& Halwa, (2016) pada lanjut usia keadaan hormonal yang menurun akan mengakibatkan pola tidur berubah. Meningkatnya frekuensi terbangun pada malam hari, sulit tidur kembali dan ketidak puasaan tidur sehingga tidak mencapai kualitas tidur baik.

\section{Karakteristik Responden Berdasarkan Jenis Kelamin}

Dari hasil penelitian didapatkan kesimpulan sebagian besar lansia berjenis kelamin perempuan yaitu 55 responden dibandingkan lansia yang berjenis kelamin laki laki yaitu 6 responden. Menurut Nugroho (2010) jenis kelamin dapat menjadi salah satu faktor terjadinya kualitas tidur buruk pada lansia, hal tersebut dikarenakan perempuan akan mengalami menopause pada usia lanjut. Secara fisiologis menopause dapat menyebabkan penurunan hormon estrogen dan progesteron yang mempengaruhi reseptor hormon tersebut ke dalam hipotalamus yang dapat mempengaruhi kondisi psikologis seseorang yaitu menjadi lebih emosional dan gelisah, keadaan ini dapat mempengaruhi secara langsung irama sirkardian dan pola tidur pada lansia, hal tersebut yang membuat lansia perempuan menjadi sulit untuk tidur (Potter \& Perry, 2010).

Jenis kelamin memiliki keterkaitan dengan terjadinya kadar gula darah yang tinggi. Menurut Imam Soeharto (2005), penyakit DM sebagian besar dapat dijumpai pada perempuan diandingkan laki - laki. Karena disebabkan perempuan memiliki Low Density Lipoprotein (LDL) atau kolestrol jahat tingkat trigliserida yang lebih tinggi banding laki - laki. Dan juga terdapat perbedaan aktivitas dan pola hidup sehari - hari. selain itu, peningkatan kadar lipid (lemak darah) pada perempuan lebih tinggi dibandingkan laki - laki. Sehingga prempuan cenderung lebih tinggi mengalami peningkatan kadar gula darah daripada laki - laki.

\section{Karakteristik Responden Berdasarkan Indeks} Massa Tubuh (IMT)

Dari hasil penelitian didapatkan kesimpulan sebagian besar lansia memiliki berat badan lebih 23 orang dan gemuk 5 orang. Berat badan semakin menjadi perbincangan dalam bidang kesehatan karena efeknya yang signifikan terhadap kesehatan. Berat badan menjadi faktor penyebab kadar gula darah tinggi (Wahyuningsih, 2013). Menurut Steven dalam Astiti dkk, (2018), subjek dengan peningkatan lemak tubuh memiliki resistensi yang lebih terhadap kadar insulin tubuh sehingga berpengaruh terhadap peningkatan kadar gula darah. Didukung oleh hasil penelitian yang dilakukan oleh Ryandra, (2015) terdapat hubungan antara kualitas tidur dengan indeks massa tubuh berlebih.

Bertambahnya usia berkaitan dengan tidak teraturnya waktu tidur dan ketidakpulasan 
tidur (Pramardika, 29014 dalam Sholihah, 2019). Gangguan tidur yang terjadi seperti kesulitan tidur, sering terbangun tengah malam dan mengantuk saat siang hari. hal tersebut akan menyebabkan ketidakseimbangan hormon leptin dan ghrelin yang berfungsi sebagai hormon pereda dan perangsang nafsu makan (Cauter \& Knutson, 2008). Pada penelitian yang dilakukan Cauter \& Knutson (2008), bahwa tidur memiliki pengaruh terhadap kejadian kenaikan berat badan. Didukung oleh penelitian Adakova dkk, 2009, bahwa responden yang memiliki rentan usia 1865 tahun dengan durasi tidur kurang dari 7 jam menunjukkan IMT yang tinggi begitu juga sebaliknya dengan waktu tidur yang lama tidak disertai aktivitas fisik dan pengurangan asupan energi juga akan meningkatkan IMT.

\section{Karakteristik Responden Berdasarkan Kadar Gula Darah Sewaktu}

Dari hasil penelitian didapatkan kesimpulan sebagian besar lansia memiliki kadar gula darah sewaktu prediabetes sebanyak 33 orang $(54,1 \%)$ dan diabetes sebanyak 5 orang $(8,2 \%)$. Diabetes melitus rentan terjadi pada rentaaan usia 50 - 60 tahun (Tentro dkk, 2016). Secara fisiologi dengan penurunan proses metabolisme endokrin sehingga terjadinya resistensi insulin berakibat peningkatan kadar gula darah (Isnaini \& Ratnasari, 2018). Dalam kondisi kadar gula darah tinggi menyebabkan urine menjadi lebih kental dan membutuhkan air untuk mencairkannya. Akibatnya tubuh akan mengalami dehidrasi sehingga pasien DM menjadi banyak minum, maka akan menjadi lebih sering buang air kecil saat malam hari (Simanjuntak, 2018). Gejala tersebut terjadi sebagai akibat tingginnya kadar gula darah sehingga menyebabkan diuresis osmosis, kondisi ini yang memicu gangguan tidur pada penderita yang beresiko diabetes melitus (Wahyuningsih, 2016).

\section{Karakteristik Responden Berdasarkan Kualitas} Tidur

Dari hasil penelitian didapatkan kesimpulan sebagian besar lansia memiliki memiliki kualitas tidur buruk yaitu sebanyak 55 orang $(90,2 \%)$ dari 61 responden. Kualitas tidur lansia yang buruk dapat dipengaruhi oleh beberapa faktor seperti, lingkungan, penyakit fisik, gaya hidup, stress dan usia. Pada lansia yang mengalami perubahan kualitas tidur dan kuantitas tidur merupakan dampak dari proses penuaan (Wahyuni dkk, 2009). Menurut Lou dkk, 2014 kualitas tidur yang buruk dan durasi tidur yang pendek dapat merusak regulasi glukosa. Kadar leptin akan menurun dan sensitivitas insulin berkurang, penurunan sensitivitas insulin tidak dikompensasi oleh peningkatan pelepasan insulin akibatnya hal tersebut meningkatkan resiko diabetes dan toleransi glukosa terganggu (Irawati, 2020).

\section{Hubungan Kadar Gula Darah Sewaktu dengan} Kualitas Tidur pada Lansia Beresiko Diabetes Melitus di Desa Kincang Wetan Kota Madiun

Hasil penelitian pada analisa data yang telah dilakukan disimpulkan terdapat hubungan kadar gula darah sewaktu dengan kualitas tidur pada lansia yang beresiko diabetes melitus di Desa Kincang Wetan Kota Madiun. Dengan arah hubungan yang positif yang berarti semakin tinggi kadar gula darah sewaktu akan diikuti dengan peningkatan skor kualitas tidur. Perubahan pada lansia yang disebabkan oleh proses penuaan berdampak pada masalah fisik, kadar gula darah tinggi merupakan salah satu masalah yang diakibatkan oleh adanya gagguan sekresi insulin dan menjadi resiko terjadinya diabetes melitus yang rentan terjadi pada lansia. (Nugroho, 2008).

Diabetes melitus suatu kondisi dimana kadar glukosa didalam darah tinggi karena tubuh tidak dapat menggunakan insulin secara cukup sehingga mengakibatkan terjadinya penumpukan 
glukosa dalam darah yang menyebabkan hiperglikemi (Kerner \& Bruckel, 2014 dalam Ozougwu, 2013). Glukosa secara normal bersirkulasi dalam darah dalam jumlah tertentu. Glukosa didalam tubuh dibentuk didalam hati dari makanan yang dikonsumsi. Insulin adalah hormon yang diproduksi oleh pankreas yang berfungsi untuk mengendalikan kadar gula dalam darah dengan mengatur produksi dan penyimpanannya. Defesiensi insulin menyebabkan penggunaan glukosa darah dalam plasma tinggi atau hiperglikemia (Kerner \& Bruckel, 2014 dalam Ozougwu, 2013).

Proses degenaratif juga dapat mempengaruhi proses hormonal di dalam tubuh. Usia lanjut dapat menyebabkan penurunan hormon kortisol, peningkatan aktivitas sistem saraf parasimpatis, penggunaan glukosa oleh otak menurun, peningkatan Non-Esterified Fatty Acids (NEFA), penurunan hormon leptin dan peningkatan Growth Hormone (GH) (Arieselia, 2014). Hormon kortisol dan hormon leptin memiliki fungsi yang sama yaitu sebagai pembentukan metabolisme glukosa (gluconeogenesis) (Arieselia, 2014). Pada malam hari dengan keadaan sulit tidur kortisol meningkat dan leptin menurun, hepar akan merangsang pembentukan glukosa dari lemak dan protein yang tidak mengandung karbohidrat dan akan menghambat penggunaan glukosa (Wulandari \& Mulyono, 2019). Menurut Starr (2014) dalam Wulandari \& Mulyono (2019) jika terjadi gangguan irama sirkardian akan direspon tubuh sebagai stressor yang akan berpengaruh dalam peningkatan kortisol pada malam hari. Penelitian yang dilakukan Morton \& Schwartz (2011) penurunan leptin mengakibatkan terganggunya metabolisme glukosa oleh otak, sehingga mengalami peningkatan kadar gula darah. Didukung oleh penelitian Haque dkk, 1999 dalam Arieselian 2014 kortisol dan leptin memiliki efek yang sinergis dengan insulin diperifer sehingga terdapat peningkatan penyerapan glukosa oleh jaringan. Oleh karena itu, penurunan leptin dan peningkatan kortisol saat keadaan kurang tidur mengakibatkan peningkatan kadar gula darah (Arieselia, 2014).

Selain kortisol dan leptin, Non-Esterified Fatty Acids (NEFA) juga berperan dalam pengaturan produksi glukosa. Di keadaan kurang tidur NEFA akan meningkat dan menekan produksi glukosa oleh hepar sehingga peningkatan kadar NEFA akan meningkatkan jumlah dan laju produksi glukosa atau (gluconeogenesis). NEFA juga akan meningkatkan kadar prekursorglukoneogenik dan penyerapan ke dalam hepar sehingga mendukung peningkatan produksi glukosa oleh hepar (Arieselia dkk, 2014).

Didalam darah kadar dan durasi growth hormone (GH) dapat meningkatkan kadar gula darah pada keadaan kurang tidur. GH berperan sebagai Glucoregulatory Hormone. GH berfungsi untuk mempertahankan kadar gula darah ketika tidur dengan cara menurunkan penyerapan dan penggunaan glukosa oleh otot dan menstimulasi produksi glukosa oleh hepar. Tetapi jika kadar GH tinggi didalam tubuh untuk durasi yang lebih panjang menyebabkan peningkatan kadar gula darah pada keadaan kurang tidur. Penelitian Rizza dkk, 1982 dalam Arieselia, 2014, membuktikan peningkatan kadar GH yang terus - menerus menyebabkan peningkatan kadar gula darah, disebabkan oleh terganggunya fungsi insulin untuk menekan produksi glukosa dan merangsang penggunaan glukosa.

Ketika tubuh sedang mengalami peningkatan kadar gula darah, glukosa yang berlebihan diekskresikan ke dalam urin, ekskresi ini akan disertai pengeluaran cairan dan elektrolit yang berlebihan. Keadaaan ini dinamakan diuresis osmotic. Kehilangan cairan yang berlebihan menyebabkan pasien akan mengalami peningkatan dalam berkemih (polyuria) dan peningkatan rasa haus (polydipsia). Pada penelitian sebelumnya yang dilakukan oleh 
Tentro dkk, (2016) kadar gula darah yang tinggi memiliki hubungan yang signifikan dengan kualitas tidur. Diperkuat dengan penelitian yang dilakukan Parish (2009), pasien yang menderita hiperglikemi umum mangalami gangguan tidur akibat dari gejala yang ditimbulkan. Sesuai dengan pendapat Surani dkk, 2015 dalam Wahyuningsih (2016) menyatakan bahwa pasien yang memiliki kadar gula darah tinggi dapat mengalami kesulitan tidur karena nocturia, sindroma kaki gelisah, neuropati perifer dan sleep apnea ketika malam hari. Ditambah dengan bertambahnya usia dan proses penuaan, akan berdampak pada pola tidur seseorang (Wolkove dkk, 2007). Didukung oleh penelitian dari Ip \& Mokhlesi (2009) yang menyatakan bahwa terjadinya kualitas tidur buruk pada pasien yang beresiko diabetes melitus akibat dari gejala dan perubahan hormon yang dapat mempengaruhi mekanisme proses hormonal yang mempengaruhi tidur (Roizen \& Mehmet, 2009). Tidur yang cukup merupakan salah satu kebutuhan dasar yang harus dipenuhi oleh setiap individu, terutama pada lansia yang sangat beresiko mengalami diabetes melitus. Peningkatan kadar gula darah yang sewaktu-waktu bisa mempengaruhi kualitas tidur, sehingga terjadi penurunan kemampuan dalam melakukan aktivitas sehari - hari.

\section{KESIMPULAN DAN SARAN}

Kadar gula darah sewaktu pada lansia di Posyandu Desa Kincang Wetan Kota Madiun memiliki klasifikasi prediabetes. Kualitas tidur yang dimiliki lansia di Posyandu Desa Kincang Wetan Kota Madiun cenderung buruk dan terdapat hubungan cukup kuat kadar gula darah sewaktu dengan kualitas tidur pada lansia beresiko diabetes melitus di Posyandu Desa Kincang Wetan Kota Madiun.

\section{UCAPAN TERIMAKASIH}

Penulis mengucapkan terimakasih kepada Ibu Nungki Marlian Yuliadarwati dan Ibu Atika Yulianti selaku dosen pembimbing yang telah membimbing dan memberikan dukungan, serta semua pihak yang telah membantu kelancaran penelitian ini.

\section{DAFTAR PUSTAKA}

Amir, S. M., Wunguow, H., \& Pangemanan, D. (2015). Kadar Glukosa Darah Sewaktu Pada Pasien Diabetes MelitusTipe 2 di Puskesmas Bahu Kota Manado. Jurnal e-Biomedik (eBm), 3(1).

Arieselia , Z., Tasia, Y., \& Sasmita, P. K. (2014). Pengaruh Kurangnya Jumlah Jam Tidur Terhadap Perubahan Kadar Gula Darah Pada Mahasiswa Preklinik Fakultas Kedokteran Unika Atma Jaya. Damianus Journal of Medicine Universitas Katolik Atmajaya, 13(2), 128-136.

Association, A. D. (2014). Diagnosis and Classification of Diabetes Mellitus. Diabetes Care, 37(1), 581-590.

Fatmah. (2010). Gizi Usia Lanjut. Erlangga.

Guyton, A. C., \& Hall, J. E. (2010). Fisiologi Kedokteran Edisi 11. Jakarta: Buku Kedokteran EGC.

Luo, J., Zhu, G., Zhao, Q., Guo, Q., Meng, H., \& dkk. (2013). Prevalence and Risk Factors Of Poor sleep Quality Among Chinese Elderly in An Urban Community. results from the Shanghai Aging Study.

Nugroho, W. (2008). Keperawatan Gerontik \& Geriatrik (Vol. 3). Jakarta: Penerbit Buku Kedokteran EGC.

Ozougwu, O. (2013). The Pathogenesis and Pathophysiology of Type 1 and Type 2 Diabetes Mellitus. J. Physio. Pathophysio, 4(4), 46-57.

Potter, P. A., \& Perry, A. G. (2012). Buku Ajar Faundamental Keperawatan: Konsep, 
Proses dan Praktik (Vol. 1). (7, Ed.) Jakarta: EGC.

Sari, E., \& Halawa, A. (2016). Senam Lansia Terhadap Tingkat Insomnia Pada Lansia di Panti Werdha Usia Anugerah Surabaya. 8089.

Simanjuntak, T. D., Sawaraswati, L. D., \& Muniroh, M. (2018). Gambaran Kualitas Tidur Pada Penderita Diabetes Melitus Tipe2 Di Wilayah Kerja Ngesrep. Jurnal Kesehatan Masyarakat Universitas Diponegoro, 6(1), 2356-3346.

Tentro, I. N., Pangemanan, D. H., \& Polii, H. (2016). Hubungan Diabetes Melitus Dengan Kualitas Tidur. Jurnal e-Biomedik (eBm) Universitas Sam Ratulangi Manado, 4(2), 16.

Uyun, L., Yuliadarwati, N. M., \& Utami, K. P. (2019). Pengaruh Brisk Walking Exercise
Terhadap Penurunan Kadar Glukosa Pada Lansia Potensi Diabetes Melitus di Posyandu Rampal Celaket. Universitas Muhammadiyah Malang.

Wahyuni, D., Tjekyan, R. S., \& Darmayanti, S. (2009). Kualitas Tidur dan Gangguan Tidur pada Lansia di Panti Werda Bakti Dharma KM 7 Palembang Fakultas Kedokteran Universitas Sriwijaya.

Wahyuningsih, S., Huriah, T., \& Sari, N. K. (2016). Hubungan Kadar Gula Darah Dengan Insomnia Pada Penderita Diabetes Melitus. The Indonesia Journal Of Health Science Universitas Muhammadiyah Yogyakarta, 7(1), 54-63.

Wolkove, N., Elkholy, O., Baltzan, M., \& Palayew, M. (2007). Sleep and Aging: 1. Sleep Disorders Commonly Found in Older People. Canadian Medical Association Journal, 176(9). 